\title{
Customer Experience and Journey: Emerging Aspects
}

\author{
Abdul Khader. D ${ }^{1}$, Dr. C. Madhavi ${ }^{2}$ \\ ${ }^{1}$ Research Scholar, Department of Business Administration, Annamalai University, Annamalai Nagar, \\ Chidambaram \\ ${ }^{2}$ Professor, Department of Business Administration, Annamalai University, Annamalai Nagar, Chidambaram \\ *Corresponding Author: Abdul Khader. D, Ph. D. Research Scholar, Department of Business \\ Administration, Annamalai University, Annamalai Nagar, Chidambaram
}

\begin{abstract}
The aim of customer experience and journey management is to create a long-lasting relationship with customers and facilitate customers get bonded to a brand. Delivering sustainable and distinctive customer experience throughout customer journey is a key for firms to succeed and consistency remains an added advantage to be competitive in today's fierce marketing conditions. The main objective of this paper is to determine how customer experience and journey is so important in defining customer service strategies. Creating strong and positive experiences within the customer journey will determine the success of business. This study attempts to shed some light on the customer decision processes, factors that affect customer experience and aspects to be considered for creating better customer experience journey. In the recent past, the researchers and practitioners have mainly focused on conceptualizations and generalizations of customer experiences, now it has emerged that customer experience is one of the important challenges for the firms to consider, in the coming time, customer experience will emerge at the center stage, likely because of the increasing number and complexity of customer decision process phases and customer touch points, and the belief that creating a sustainable positive experience within the customer journey will impact bottom line and performance of the firms. Given current economical situations, retaining an existing customer significantly improve bottom line and reduce cost of acquiring a new customer as it will result in word-of-mouth marketing and customer loyalty. This study reveals that structured customer experience journey will lead to greater organizational results and customer service satisfactions.
\end{abstract}

Keywords: Customer experience, Customer journey, Touch points, Customer experience management, Customer buying decision process, and Profitability

\section{INTRODUCTION}

Creating imperative customer experience and transforming that customer experience journey into successful service quality strategy is one of the paramount priorities of today's business environment. Creating long-lasting strong customer experience journey is a way for the survival. Improving customer experience can be the answer for many companies to stand out in the crowd, as they trade in competitive environments with increasing customer expectations. Most firms know that customer service at every touch point, regardless of the communication method, must provide a positive experience every time so they don't lose any opportunities or damage their brand. This study is based to functional sectors of automobiles.

Firms require to find new ways to get their brands or services included in the initial enquiry, comparison, evaluation, and consideration stages that customers develop as they begin their buying decision journey. And also, need to focus on more systematic ways to satisfy customers' needs and manage post-purchase phase as they create customer loyalty and an effective tool of word-of-mouth marketing approach. In the past few years, in the process of managing customer experience journey, attention has been gradually shifting to touch-points (touch points are such as advertisements, references, word-of-moth, news reports, and conversations with family and friend, product or service experiences) and customer experience management philosophies. Many companies, such as Amazon, Google, Flipkart, GM, and HDFC now have customer care center, customer experience officers or managers responsible for creating and managing the journey of experience of their customers.

\section{DEFINITION OF CUSTOMER EXPERIENCE AND JOURNEY}

The terms 'customer experience' and 'customer experience management' are receiving increasing attention in both the academic and managerial literature (Pennie Frow and Adrian Payne, 2007). A 
definition of customer experience in our view is managing customer interactions in a strategically manner with a brand or company, specifically, is the concept of superior customer experience as an evolution of the concept of creating positive perceptions and willingness in customers' mind towards a product or service with the goals of achieving long-term benefits. However, meaning of customer experience varies from company to company, people to people and industry to industry. According to Gentle C. et al., (2007 p 397), "The Customer Experience originates from a set of interactions between a customer and a product, a company, or part of its organization, which provoke a reaction (LaSalle and Britton, 2003; Shaw and Ivens, 2005). This experience is strictly personal and implies the customer's involvement at different levels (rational, emotional, sensorial physical and spiritual) (LaSalle and Britton, 2003; Schmitt, 1999). Its evaluation depends on the comparison between a customer's expectations and the stimuli coming from the interaction with the company and its offering in correspondence of the different moments of contact or touch-points (LaSalle and Britton, 2003; Shaw and Ivens, 2005)." It is interesting to point that new research reveals that young folks (age between 25 -35 years) are more concerned about their experience than others that they have with encounters and affect future course of firms' business.

In the last few years, customer experience and journey had caught significant attention of researchers and practitioners. In the past, the literature in the marketing, customer experience has not considered as separate construct, researchers and practitioners focused to study customer experience either with customer service as a whole or the part of service quality to determine the difference between customer perceptions and expectations during their service encounters. Nowadays, a great deal of consideration is focused towards customer experience and journey as a separate subject of study by many philosophers, managers and researchers.

Customer experience journey evolves around setting of right environment for customers to cruise smoothly during purchase and post-purchase phases and firms are increasingly worried to retain their current customers and finding new ways to improve customer experience. Recent study indicates that cost of acquiring a new customer is four times more than retaining an existing customer. Katherine \& Peter (2016) argued that the increasing focus on customer experience dominating because customers now interact with firms through numerous touch points in multiple channels and media, resulting in more complexity of customer journeys. Control of firms managing customers is shrinking as peer customers influencing customer experience and journey. In economic terms, retaining an existing customer is far most important in performance and profitability point of view as acquiring a new customer is cost-involved and it is increasingly becoming difficult and hence customer experience regarded as the top most priority for the survival of a firm. Companies have embraced customer experience closely behind products and services.

\section{Customer Buying Decision Phases}

Customers have been holding upper hand when it comes to making buying decisions. From social media to mobile services, IT has given customers distinctive power to evaluate information, compare prices, demands are met and best deals are done. This led to balance of benefits go in favor of customers has been found evident for years and profit margins of firms shrinking but firms are fighting back to regain. From the point of customers have a need until they considered buying- is called as a customer buying decision process (Figure 1). Company that manages these phases of customer preferences well can radically change buying and ownership cycle into customer loyalty and can create holistic customer experience and journey.

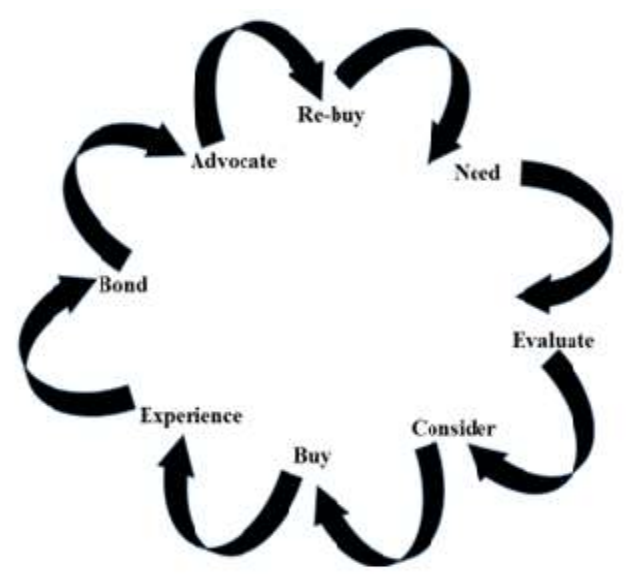

Picture1. Customer buying decision process 


\subsection{Need}

The very first stage of buying decision phases is customer to have a basic or specific need of a product or a service or a requirement for him or her to acquire. Truly understanding customer needs may help companies not only improve buying experience but also influence customers to lean to their products or services. Understanding the customer experience journey is about determining from the moment when customer has a need followed by subsequent phases of buying decision process.

\subsection{Evaluate}

Customer starts evaluating firm's offer of products or service as soon as he or she decides to own a particular need. In recent years, customers have an access of unprecedented sources of social media and mobile services and flooded with massive kinds of information. Firms are also coping up and confronted with media and channel fragmentation, and advancing marketing approaches. To find the best deals, customers collect information from multiple sources, comparing the information to suit against various available choices. They evaluate extensively before considering buying choices.

\subsection{Consider}

Moment evaluation is narrowed down over multiple choices, at this point customer makes a choice to consider to buy. Firms should make relentless efforts to appease at customer pre-consider phase in order to penetrate and win over customer buying preferences. Not to forget that aggressive customers will consider to buy only after evaluating every best option that is not only beneficial for him or her but also get a very best buying deal.

\subsection{Buy}

Broadly, there are three steps in buying process, pre-purchase stage, purchase stage, and postpurchase phase. Pre-purchase phase covers- need, enquiry, comparison, evaluation, and consideration. The next main phase is purchase - covers all customer interactions that he makes with firm to avail a brand or service and its environment during the buying event. It is characterized by behaviors of choice of preferences, ordering, waiting time, courtesy of staff, payment, and finally owning it. Firms should able to understand customer preferences at purchase phase carefully and should leave no stone unturned to make it delightful event.

\subsection{Experience}

After customer owning a brand or service, at this stage it becomes a critical touch point and depends largely post-purchase engagements and interactions with a firm. Creating strong and eventful encounters will lead to positive customer experience and it is important to keep customers coming back to service events. Unlike purchase - it is mostly one-time event and that post-service is the phase of multiple events. Practically this stage covers characteristics of customer's experience after purchase that some way or other relate to performance of a brand or service. Given this perspective of customer buying decision journey, firms should incorporate best service strategies to satisfy customers. First, firms should seek to understand customers' needs clearly and meet them every time they visit. Second, prepare customer inter-facing staff and processes to fulfill customer perceptions and expectations. Finally, identifying the specific elements of interaction points that need to be fine-tuned. Reports suggest that one satisfied customer will hardly tell 2-3 customers and one dissatisfied customer can ruin over 10 customers.

\subsection{Bond}

One key element of understanding and managing customer experience journey is the ability to scale and monitor customer reactions to firm's offerings and willingness of customers to stay with brand or service and persuade others through references to purchase. Delighted customers will always bond with the brand, significant improvement of interactions with the customers will make customers keep coming back to that particular brand.

\subsection{Advocate or Switch}

Firms should identify to trigger out bottle-necks to lead customers to continue doing business and avoid switching over to others in their customer experience journey. Delighted customers who always make advocacy for the firms through word-of-mouth and distinctive references. They will tell his 
family and friends when they get good customer experience. Dissatisfied customers not only switch to competitors but also make their way taking other customer along with them.

\subsection{Re-buy}

Customers who get good buying experience tend to come back and make re-purchases. This makes buying cycle complete and keep repeating it. Customers' decisions to return to a brand or service mainly characterized by the smooth sailing of their buying and ownership experience and journey. It may lead to complete loyalty to a brand or start considering for alternatives if they find customer experience is poor. Managing customer experience touch points effectively and creating potential leverage points in the customer experience journey will impact to mutual win-win situation for both firm and customer.

\section{Literature OF CUSTOMER EXPERIENCE AND JOURNEY}

An important task when studying customer experience is a clear understanding of the customer journey. In the customer journey analysis, companies focus on how customers get interacted though multiple touch points - moment from: customer has a need, enquiry, search, consideration, purchase, experience, bond, advocacy to re-purchase point. Customer journey analysis has its base in both customer management and multiple channel management (Neslin et al., 2006; Bitner et al., 2008). The most developed aspect of customer journey analysis is in the multi-channel literature (Katherine \& Peter, 2016). Early years, customer experience studies focused on the choice of specific channels such as, direct mailings and catalogs (Eastlick and Feinberg, 1999; Leaflang et al., 2013), online channels (Venkatesan et al., 2007; Ansari et al., 2008) and mobile channels (Wang et al., 2015). Since the arrival of e-commerce recently, enormous studies focused towards the pros and cons of ecommerce applications. A number of studies have emphasized on the importance of managing customer experience resulting in customer loyalty.

Customer's choices of buying are not static rather keep changing, they have multiple tendency of shopping habits - "showrooming" (search in store, buy online) and "webrooming" (search online, buy in stores) as studied by the researches (Brynjolfsson et al., 2013; Rapp et al., 2015). The concept of customer experience was firstly conceived in the mid-1980s along with the mainstream literature in consumer behavior that deemed customers as rational decision makers (Gentle C.et al., 2007). There has been remarkably limited discussions relating to the idea of a perfect customer experience in the academic literature taken place (Pennie Frow and Adrian Payne, 2007). A more recent customer experience measurement tool, the 'Net Promoter Score' (NPS) proposed by Fred Reichheld and most recently adopted by General Motors Middle East Operations in their TNS customer survey, involves asking a one major question; 'How likely is that you would recommend company to a colleague or friend?' The NPS is calculated by the taking the share of customer 'promotes' on a 10-point scale. Customer experience survey is categorized into 3 groups, namely Promoters ( 9 or 10) are loyal, enthusiastic and they tend to account for more than 80 percent of referrals in most business. A Passively satisfied ( 7 or 8 ) customers, this group is satisfied - for now, and Detractors (0 to 6) and dissatisfied customers. A Net Promoter Score is calculated simply - the percentage of promoters minus the percentage of detractors (Figure 2). The Net Promoter System is much more than just the score (Reichheld, 2003) and customers are asked to rate through an unstructured, open-ended question about their experience. Globally, there are over 200 companies adopted NPS to measure customer experience feedback.

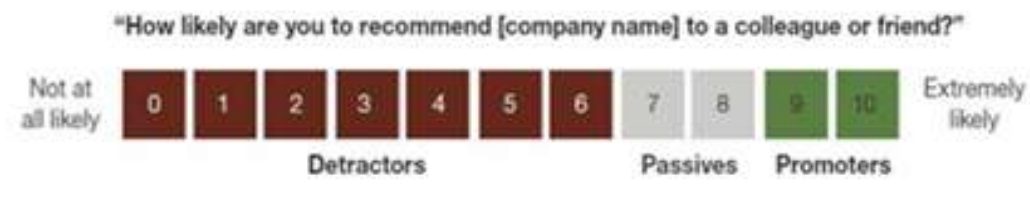

Net Promoter calculation examples:

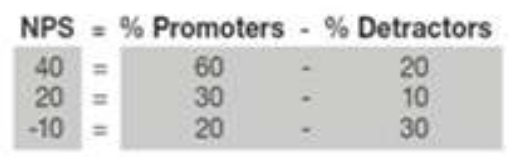

Source: GM TNS Survey

Picture 2. Net promoter score 
Companies have been adopting customer experience as a tool to obtain sustainable competitive advantage (Shaw and Ivens, 2005). However, lack of literature and research on customer experiences is echoed by researchers on the methods implemented to collect and illustrate customer experience data (Hill et al., 2002; Stuart and Tax, 2004; Verhoef et al., 2009). Major research on the customer experience mainly focused on the customer's expectations and perceptions side of service event (Parasuraman et al., 1984; Cronin and Taylor, 1992; Teas, 1993; Griffin, 1995; Zeithaml and Bitner, 1996; Gitomer, 1998) and service quality theories (Grönroos, 1982; Parasuraman et al., 1984).

\section{RESEARCH APPROACH AND STUDY}

This study takes into consideration the roles of leadership, customer interacting staff, and customers in determining the customer experience and journey management. Observation method, survey - both explorative and descriptive in nature and qualitative scale approach are adopted for this study. Study was conducted at selected cities in automotive sales and after sales network in Saudi Arabia. The research has been carried out in two phases. In the first part, encounters of front-line employees with customers, usually it is called as a customer experience journey is documented through the observation method. In addition, employees have been asked to provide further information to enhance observational data. In the second part, customer experience analysis has been performed through the structured survey approach. Customer experience survey was carried out by means of a structurally formatted questionnaire with a multiple choices, rating and agreement scale questions on a 1-5 Likert scale, 5 (is strongly agree) and 1 (is not at all agree) point feedback.

Note that the relative quality rankings through the structured analysis produced by these data were consistent with the relative performance of companies and customer experience feedback corresponding to the results produced by the firms and vice versa. Structured survey through the adequately formatted questionnaire was to seek the customer feedback on their customer experience and data obtained from the observations of front line employees and pre-determined interviews of managers to compile the qualitative analysis. It is no doubt that customer experience management is a big challenge for all the companies. Simultaneously, it is found that seeking such data and customer feedback is also a huge challenge.

Two considerations have been drawn in conducting the study. Firstly, adopt factor analysis of customer feedback of scoring the experimental components actually being perceived by the customers, secondly potential qualitative observational feedback of managers and employees pertaining to customer and management perceptions of customer experience construct. It is noticed that whereas participation of employees' and managers' penetration rate is over ninety percent and customer response rate is below eighty percent. Interestingly, customers who participated in the survey are more enthusiastic and willing to provide information as compared with employees and managers. That shows that customers are in more demanding role and management should take a note of this inclining interest towards customer experience.

\section{Customer Experience STUdy Findings}

Findings are presented in the proceeding paras in a nutshell manner. Study outlines that many companies are struggling to come with an effective and structured customer experience practices (Figure 3). One third of organizations feel that managing customer experience as an important priority and most are lacking with a sustainable and consistent customer experience strategies. Thirty percent of companies view that properly managed customer experience interactions yield better results but they still fail to draw proper customer experience roadmap. Only twenty five percent companies have an inherent belief in their customer experience strategies, they are investing on customer experience strategies exceptionally and as a result these companies perform substantially well across business functions - profitability, customer loyalty, and advocacy.

Vast majority of respondents agree that an efficient customer experience management will produce incredible results. Fifty five percent customer interactive staff say that their organizations do not support customer experience practices with ample investments and initiatives. More than half respondents felt that their firms lacking a set of processes, standards, and an automated ERP System. Critical point is that over sixty percent front-line staffs agree that customer experience program is a vital for firms to grow but do not participate to implement as they are not enthusiastic for various reasons (For e.g., lack of empowerment, recognition, motivation etc.). 


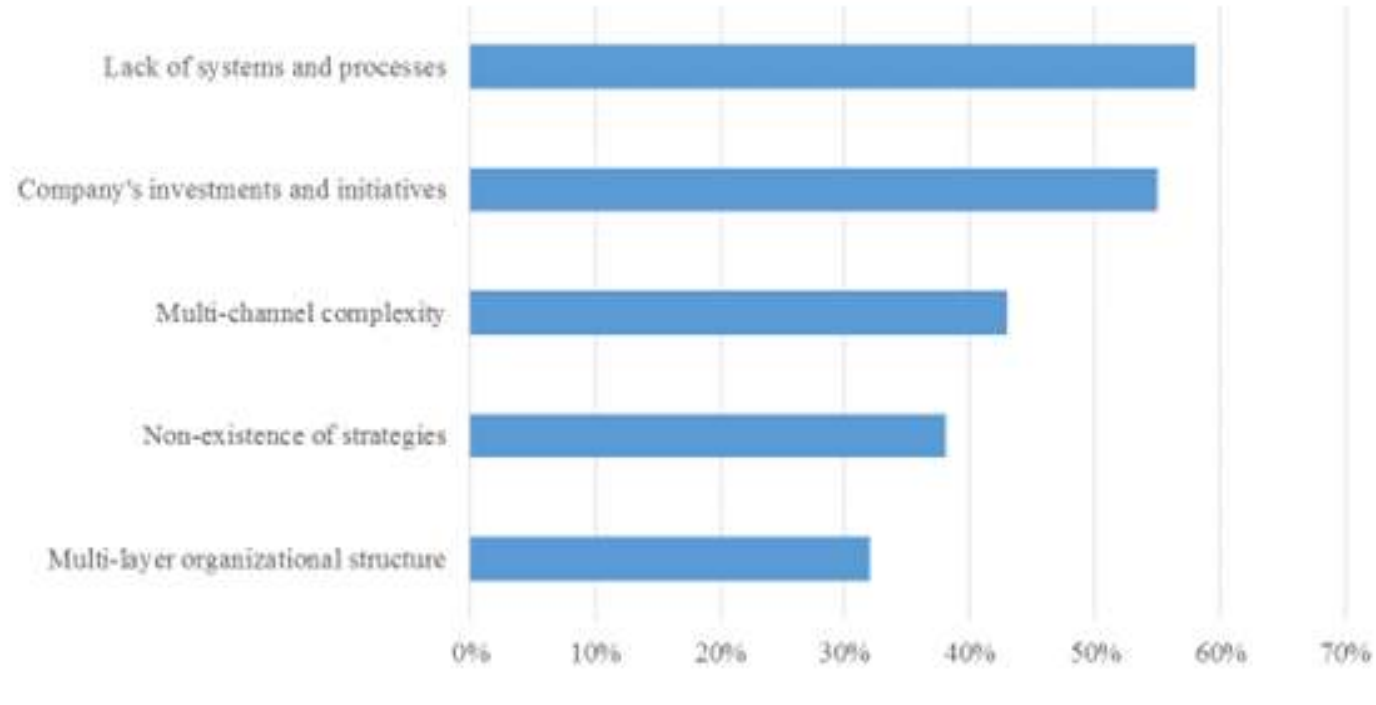

Picture 3. Hurdles of customer experience management

When analyzing success of firms' customer experience, it has been observed series of customer behaviors towards a band or company, that not only improved customer experience journey but also increased company's profitability and customer retention rate. Positive customer's behaviors are replicable in optimized results, such as; (customers):

- Keep buying

- Stay bonded

- Refer friends and family

- Provide feedback and suggestions

- Make long relationship

- Help togrow

- Active participation

Together with an efficient customer experience strategy and an active participation of customers in the customer experience journey, it has been evident that companies are gaining a clear breakthrough advantage as a result of their efforts and practices. One potential limitation of customer experience analysis is that the data used to construct above metrics may not applicable across the industry or firms of all kinds. What genuinely felt is that it may suit for the firms with the combination of sales and after sales activities.

\section{Customer Experience Aspects And ChallengeS}

The concept of customer experience management has been around for quite some time now, and the customer journey practices gaining momentum. Although, most companies view customer experience programs are important but they fail to adequately adopt customer experience efforts, even some companies pushing hard and consistency is hindering the whole strategy. Many companies face a number of challenges in adopting customer experience programs, from providing sufficient financial fund, proving potential financial value of customer experience to making organizational culture change. As the customer expectations continue to grow, managing multiple channel customer touchpoints remains focal point of customer experience management. Integration of people, processes, standards, controls, system, and technology is the main challenge for the firms handling below aspects of customer experience management.

- Multiple touch points

- Consistency

- Moments of truth

- Committed leadership 
- Committed employees

- Role of Information Technology

- Role of CRM

Managing multiple touch points in the customer experience stays ahead in the list and consistency is the one that every company should focus to keep the momentum moving. Customer perceptions are influenced based upon the moments of truth that customers come across. Committed leadership and frontline staffs should take the lead in customer experience management, Role of CRM and IT play big role in devising and managing customer experience practices and programs.

\section{Concluding Thoughts}

Achieving desirable customer experience is remarkable goal for the firms aiming to enhance advocacy and profitability. In the concluding section of this paper, customer experience insights are presented, limitations of this study and some thoughts for the future research opportunities. It is observed that effectively managing customer touch points leading to an enhanced customer experience was evident in the course of study. Despite the recognition of the importance of customer experience journey, quality of customer experience is declining and some customers often feel that they get service quality that lags below their expectations.

In addition to the above, it is believed that customer experience is holistic in nature and involves active participation of customers, committed customer-centric employees, well defined processes, and committed management to create enhanced customer experience journey. How to judge that wellstructured customer experience is created and delivered every time? Answer is that customer is willing to recommend a brand or service to his or her friend or colleague over and again. Observations of the study suggest that customer experience-based strategy incorporates growth. Some of the factors identified in the study are given below and that to be handled sufficiently during the course of customer experience management.

- Gap analysis

- Process mapping

- Management of customer-buying decision phases

- Interaction touch-points analysis

- Standards and controls activity cycles

It is our belief that the findings of this analysis will be beneficial for managers and practitioners for the future studies on the customer experience and journey management. Determinants of customer experience and journey are dynamic with nature and model of business. Organizations are in hurdles seeking to improve their business, customer experience management is the best approach for them to grow. Researchers and practitioners need to take customer experience management to further levels with potential development of literature. Customer experience in the marketing literature will grow to meet the competition, customer demands, and optimization of performance.

\section{REFERENCES}

[1] Katherine N. Lemon \& Peter C. Verhoef (2016), "Understanding Customer Experience Throughout the Customer Journey”, Journal of Marketing, Vol. 80, pp. 69-96.

[2] Gentle C.et al., (2007), "How to Sustain the Customer Experience: An Overview of Experience Components that Co-create Value With the Customer", European Management Journal, Vol. 25, No. 5, pp. 395-410.

[3] David Edelman and Marc Singer (2015), "The new consumer decision journey", McKinsey Digital, October 2015 Issue, McKinsey \& Company, p. 1-3.

[4] Pennie Frow and Adrian Payne (2007), "Special Issue Papers Towards the 'perfect' customer experience”, Brand Management, Vol. 15, No. 2, p. 89-101.

[5] Fred Reichheld (2003), "Net Promoter System”, Brain \& Company

[6] Verhoefet al., (2009), "Customer Experience Creation: Determinants, Dynamics and Management Strategies", Journal of Retailing, Vol. 85, pp. 31-41. 
[7] Christian Grönroos (1988), “A Service Quality Model and its Marketing Implications”, European Journal of Marketing, Vol. 18, No. 4, pp. 36-44.

[8] Berry et al., (1985), “Quality Counts in Services, Too”, Business Horizons, pp. 44-52.

[9] Zeithaml et al., (1990), "Delivering Quality Service, Balancing Customer Perceptions and Expectations", The Free Press, New York.

[10] Buellet al., (2016), “How Do Customers Respond To Increased Service Quality Competition?” Working Paper, Harvard Business School, 11-084, pp. 1-35.

[11] Teixeiraet al., (2012) "Customer experience modeling: from customer experience to service design”, Journal of Service Management, Vol. 23, No.3, pp. 362-376.

[12] Richard W. Mosley (2007), "Customer experience, organizational culture and the employer brand", Brand Management, Vol. 15, No. 2, pp. 123-134.

[13] Robert Johnston and Xiangyu Kong (2011), "The Customer Experience: A Road Map for Improvement", Managing Service Quality, 21(1), pp. 5-24.

[14] Guteket al., (2002), "Achieving service success through relationships and enhanced encounters", Academy of Management Executives, Vol. 16, No. 4, pp.132-145.

[15] McColl-Kennedy et al., (2015), "Fresh perspectives on customer experience”, Journal of Services Marketing, Vol. 29 (6-7), pp. 430-435.

\section{AUTHORS' BIOGRAPHY}

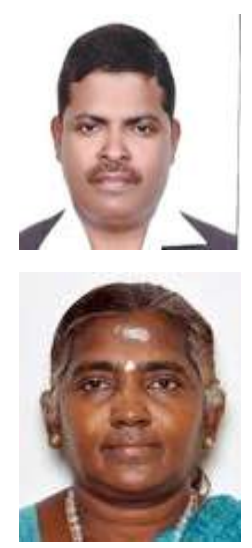

Abdul Khader. D is a Ph.D. Research Scholar in the Department of Business Administration at Annamalai University. He has over two decades of industry experience in the functional sectors of automobile aftersales and customer experience operations.

Dr. C. Madhavi is a Professor in the Department of Business Administration at Annamalai University. She had B.Sc., MBA, M.Phil., Ph.D. She has guided for 15 M.Phil. And Ph.D. scholars and has 32 years of teaching experience.

Citation: Abdul Khader.D, Dr. C. Madhavi. "Customer Experience and Journey: Emerging Aspects" International Journal of Managerial Studies and Research, vol 5, no. 10, 2017, pp. 22-29. doi:http://dx.doi.org/10.20431/2349-0349.0510003.

Copyright: (c) 2017 Authors. This is an open-access article distributed under the terms of the Creative Commons Attribution License, which permits unrestricted use, distribution, and reproduction in any medium, provided the original author and source are credited. 